\title{
Об астральной мифологии и ее исследованиях
}

\author{
Андрес Куперьянов \\ Отделение фольклористики, Эстонский литературный музей, \\ Эстония \\ cps@folklore.ee
}

\begin{abstract}
Аннотация: История изучения астральной мифологии в Европе имеет почтенный возраст. Она тесным образом связана с открытием и толкованием памятников античной культуры. Собирание, издание и изучение астрального фольклора и мифологии финно-угорских народов (в том числе прибалтийско-финских) также имеет долгую историю. Поэтому можно сделать некоторые обобщения об исследовательской деятельности, проводившейся до сих пор, и поднять вопросы о новых возможностях исследования.

В 1902 году выдающийся собиратель эстонского фольклора Якоб Хурт издал книгу об әстонской астрономии. В 1968 году вышел в свет обзор, составленный физиком Паулем-Эгоном Прюллером. Оба эти издания являются эмпирической систематизацией. В обеих книгах на первом месте находятся названия звезд, а верования и мифы остались в стороне. В то же время многие астральные мифы более сотни лет были в списке обязательной школьной литературы. В книге Андреса Куперьянова «Eesti taevas. Uurimusi ja tõlgendusi» (Эстонское небо. Исследования и интерпретации), вышедшей в 2004 году, охвачен весь материал Тартуского фольклорного архива и Таллинского архива эстонского языка и впервые дан систематический обзор астральных поверий, их практического использования (при определении времени и направления), астральных мифов, а также представлен дополненный указатель названий звезд. В книге также имеется карта звездного неба с указанием эстонских народных названий звезд. Менее масштабные исследования по прибалтийско-
\end{abstract}


фринским традициям, опирающиеся на полевые материалы и опубликованные ранее тексты, изданы также по води и ливам.

Все корпусы по прибалтийско-финским народам указывают на то, что собирание народных астральных знаний было начато слишком поздно, а при планировании собирательской работы был допущен ряд ошибок. Несмотря на это, прибалтийско-финские поверья выделяются в некое знание с общими чертами, мифы схожи с германскими и славянскими, хотя в них также имеется ряд особенностей и мотивов, появившихся в XX веке. В нынешней ситуации вопрос заключается в том, как и какую часть астральной мифологии необходимо собирать для пополнения имеющихся знаний и получения новых.

Ключевые слова: Народная астрономия, этноастрономия, археоастрономия, палеоастрономия, народное верование, история исследовательской деятельности

\section{1. Исторический обзор ранних тематических источников}

\section{1 Словари}

Самые ранние печатные издания об известных небесных телах датируются XVII веком. В 1637 году автор первого эстонско-немецкого словаря и составитель грамматики эстонского языка, переводчик церковных книг и песенников, которые использовались сотни лет, Генрих Шталь (Heinrich Stahl 1600-1657) опубликовал в своем труде "Anführung zu der Esthnischen Sprach" названия звезд (techt) и лунных фраз (молодой месяц, старый месяц, полнолуние, стареющая луна [последняя четверть]) (Stahl 1637). Некоторые примеры добавили Генрих Гесекен (Heinrich Göseken 1612-1681), который занимался грамматикой эстонского языка и церковной литературой, в своем произведении "Manuductio ad Linguam Oesthonicam» (1660), а также в XVIII веке әстонский лидер переводчиков Библии Антон Top Хелле (Anton Thor Helle 1683-1748), который прекрасно владел эстонским языком. Работа последнего из упомянутых авторов под названием "Kurtzgefaszte Anweisung zur Ehstnischen Sprache" в плане материала опиралось преимущественно на большой словарь Саломо Генриха Вестринга (Salomo Heinrich Vestring 1663-1749) «Lexicon Esthonico Germanicum». В словаре 
Вестринга содержится несколько названий созвездий (например, Большая Медведица, Волк возле Быка, Новое Сито и Старое Сито, выражение «когда Сито уходит в рассвет») и прочие материалы, основанные на мифрах.

В рукописном словаре южно-эстонских диалектов, составленном Йоганном Кристофом Кларе (Johann Christoph Clare 1692-1743), под названием «Cellarius Esthonico-Germanicus oder Wörterbuch der Ehstnischen Sprache», помимо прочего, также содержится, например, южно-эстонское название кометы «хвостатая звезда». Некоторые новые названия созвездий также добавил Август Вильгельм Хупель - человек с энциклопедически- ми знаниями и широкими интересами (August Wilhelm Hupel 1737-1819), чьи произведения по-прежнему служат источником знаний о бытовой жизни и наследии эстонцев в XVII-XVIII веках. Его словарь и грамматика также опирались преимущественно на справочник С. Х. Вестринга, но использовались и произведения Й. К. Кларе и А. Т. Хелле. Названия звезд и связанные с ними выражения можно найти в обширном произведении Хупеля «Ehstnische Sprachlehre für beide Hauptdialekte» (1780), которое было издано для немцев. В главном произведении А. В. Хупеля «Topographische Nachrichten von Lief- und Ehstland I-III» (1774-1782) также содержатся календарные сведения.

\section{2 Календари, учебники и научно-популярная литература}

До работы, связанной со сбором данных, которую провел Якоб Хурт, появились до сих пор обойденные вниманием письменные источники - просветительская научно-популярная литература и издание календарей. Календари начали издаваться в Эстонии в 1720-х годах, и с того времени они издавались достаточно регулярно. Начало изданию печатной эстоноязычной школьной литературы также было положено в XVIII веке, а широко распространенные учебники и прочие школьные книги на эстонском языке начали издаваться в середине XIX века. Все эти издания, несомненно, оказали свое влияние как на местных корреспондентов, так и на самих составителей исследований и обзоров. 
Согласно Хейно Ээльсалу, астрономию в эстонских школах начали преподавать с 1765 года. В конце XIX - начале XX веков космография входила в число обязательных предметов для последнего класса средней ступени (Eelsalu и др. 1976). В начальной школе также преподавали астрономию. Таким образом, в начале XX века дети заканчивали школу с достаточно хорошей подготовкой в области астрономии.

Из более ранних учебников стоит назвать учебник Г. Г. Марпурга «Weikenne oppetusse nink luggemisse Ramat Tarto ma-rahwa kooli laste tarbis» (Короткий учебник и читатель; для сельских школ), который был издан в Тарту в 1805 году. В учебнике рассматриваются такие темы, как небесный свод, Солнце, времена года, Луна и звезды. Один пример:

Se Ku, kedda meije taiwa külge näeme, om ka üts särane pimme kugel, kui meije Ilma-ma... Temma saap omma valgus sest päiwast, kelle ümbre temma meije Ilma-maga känap (Луна, которую мы видим в небе, является таким же темным шаром, как наша Земля... Она получает свет от солнца, вокруг которого она движется вместе с Землёй) (Marpurg 1805: 49).

Учебник Марпурга и книга о мироздании, которая вышла в 1794 году в качестве приложения к календарю, несомненно, стали наиболее распространенными среди народа печатными изданиями, сформировавшими новую космологию. Позднее появились книги Карла Роберта Якобсона «Kooli lugemise raamat» (Школьная книга для чтения) (Jakobson 1868) и Михкеля Кампмаа "Kooli Lugemiseraamat» (Книга для школьного чтения) (Kampmann 1913), которые являются классикой школьной литературы. В них также содержится обширная астрономическая и космологическая информация. В последней главе учебника К. Р. Якобсона «Taewa laotus» (Небеса) есть такие подразделы, как «Земной шар», «Солнце», «Путь земного шара», «Луна», «Лунные и солнечные затмения», «О звездах». В подразделе «Земной шар» Якобсон пишет, что «земля - это не одно большое круглое поле, а один очень большой шар». И еще, что «этот шар ни к чему не крепится, не имеет поддержки, а висит в поднебесье, как солнце и месяц в мировом пространстве, меж звезд». В подразделе о луне показаны лунные фазы, подробно рассказывается о том, как возникает затмение, и звезды делятся на неподвижные и блуждающие, т.е. планеты. Рядом 
споследними также указаны классические знаки планет. В качестве третьего типа небесных тел рассматриваются хвостатые звезды, т.е. кометы. Также идет речь о продолжительности года на разных планетах. Кроме того, можно почитать рассказ Фр. Р. Крейцвальда «Vaskjala silla piiga» (Девушка возле моста Васкяла), вариант сказки "Vaenelaps kuи peal» (Бедняжка на Луне) (Jakobson 1868). В учебнике М. Кампмаа по большей части повторяются те же истории, что и в учебнике Якобсона. Немного больше использовано авторизованных вариантов преданий, таких как, например, сказка Якоба Хурта о Большой Медведице, рассказ "Loomine» (Создание) Фр. Р. Фельмана. Информация о Солнце, Луне и звездах аналогичны тому, о чем говорилось в изданных ранее учебниках, книгах и приложениях к календарям, однако, в отличие от Якобсона, автор пытается использовать эстоноязычную терминологию. Например, у Якобсона используется термин fikstähed (фиксированные звезды) и латинские названия планет.

Из числа специализированных учебников наиболее известным является учебник Б. Гильденманна «Mailma made õppetus. Isseärranis Ma rahva koolmeistritte ja kolide tarwis...» (Учение о странах мира. Специально для учителей сельских школ...), изданный в 1849 году в Пярну. Учебник начинается с главы о звездах, также в нем есть описания 17 объектов солнечной системы, в т.ч. планет от Меркурия до Нептуна, а также перечислены названия девяти малых планет. Затем следует общекосмологическая информация о Земле, после чего автор начинает рассматривать географические темы (Gildenmann 1849).

В книге К. Р. Якобсона «Weikene Geograafia ehk maadeteaduse käsiraamat» (Короткая география, или справочник для науки о земле) содержится описание зодиака, старое и новое учение о мире (Птолемей и Коперник), а малых планет солнечной системы названо уже около ста. В разделе о Земле и Луне также рассказывается о тропиках (Jakobson 1868).

Среди научно-популярной литературы наиболее важны краткие статьи Фр. Р. Крейцвальда в регулярном издании «Ma-ilm ja mõnda, mis seal sees leida on» (Мир и его составляющие) (Kreutzwald 1848-1849). В первой статье даются описания Земли, Солнца и Зодиака, а также рассказывается о смене времен года. Во втором рассказывается о Луне, ее фразах, росте и убывании. Также здесь есть изображение Луны, какой она 
кажется при рассмотрении через подзорную трубу с наименьшим увеличением. В третьей статье рассказывается о блуждающих звездах - планетах, малых планетах и кольцах Сатурна. В чет-

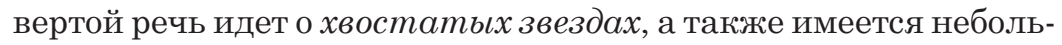
шая карта Луны. В пятой статье рассматриваются неподвижные звезды - Спицы, Сито, Медведицы, Полярная звезда, Млечный путь. Вероятно, серия «Maailm ja mõnda ...» была составлена на основе переводов и иллюстраций из журнала «The Penny Magazin», который начал издаваться в 1832 году в Англии.

\section{3 Сбор и публикация народных преданий}

Под влиянием романтизма XIX века огромную важность приобрели сбор и публикация народных преданий. Являясь хорошим знакомым лидера школы Й. Хердера, А. В. Хупель одним из первых обратил внимание на народные предания. В том же направлении продолжили работу и другие языковеды и литераторы XIX века. Хотя их работы основываются на более ранних печатных источниках, было добавлено и большое количество оригинального материала. Внимания заслуживают верования и мифологический материал. Глубокий след в культурологии Эстонии оставили Отто Вильгельм Масинг (1763-1832) и Фердинанд Иоганн Видеман (1805-1887). Оба внесли свою лепту и в увековечивание преданий о звездном небе. Первый из них опубликовал народные названия звезд и созвездий в произведении «Ehstnische Originalblätter für Deutsche» (Masing 1816), а второй-в словаре «Ehstnisch-deutsches Wörterbuch» (Wiedemann 1869). Преимущественная часть верований, связанных со звездным небом и времяисчислением, опубликованных в более ранних изданиях, а также некоторые предания собраны в книге Ф. И. Видемана «Aus dem inneren und äusseren Leben der Ehsten» (Wiedemann 1876). В ней также имеется пара десятков страниц информации, о народной астрономии. Здесь перечислены заклинания, связанные с небесными телами, метеорологические наблюдения, материал, по времяисчислению и календарю, названия созвездий и звезд, а также верования и предания по данной теме. Сразу же после публикации эстонско-немецкий словарь Видемана стал наиболее важным источником терминологии и до сих 
пор служит базовым материалом при проведении опросов, связанных с диалектами, так же, как и его произведение «Aus dem inneren und äusseren Leben der Ehsten», которое является одним из старейших базовых текстов в религиоведении.

Материал, собранный в 1817-1822 годах членами Эстонского общества Курессааре, основанного по инициативе Йоганна Вильгельма Людвига фон Люце в 1817 году на Сааремаа, был одним из старейших и наиболее обширных рукописных источников данных о народной астрономии. Он был предназначен для того, чтобы дополнить словарь А. В. Хупеля, изданный в 1780 году. К сожалению, рукопись с Сааремаа не сохранилась, однако Й. Х. Розенплантер сделал с этих материалов копию. Оказалось, что в материалах также содержатся названия созвездий и звезд вместе с кратким описанием древнего представления эстонцев о звездном небе.

\section{4 Псевдомифология}

Эстония богата псевдомифологией, которая усердно формировалась в XIX веке и в начале XX века. Часто тогдашние имена псевдомифологических персонажей того времени до сих пор используются в названиях улиц, обществ, фрирм и т.д., однако до сих пор эта тема рассматривалась на удивление редко (Viires 1991). Еще меньше внимания заслужила псевдоастрономическая карта неба, которую предложил в 1886 году писатель и журналист Адо Гренштейн. Эта карта была опубликована в качестве приложения к газете «Olevik». Целью А. Гренштейна было внедрение среди эстонцев собственной карты неба, которая была бы основана на международной стандартной звездной карте, однако не содержала бы международных названий звезд. Он предложил в общей сложности 55 названий звезд, основанных на именах мифологических существ и народных героев. Когда не стало хватать номинаций, он сам создал дополнительных персонажей. Конечно же, также используется ряд таких псевдомифологических персонажей, которые были представлены в творчестве писателей XIX века в художественной и школьной литературе. Вероятно, при составлении карты неба у А. Гренштейна перед глазами была конкретная цель создать небесный пантеон, прежде всего на базе литературного творчества. Су- 
ществующих народных названий и верований ему либо было недостаточно, либо он просто не захотел их использовать.

\section{2. Целенаправленный сбор тематического материала}

\section{1 Призыв Якоба Хурта, собиратели данных}

Первую специальную программу по сбору данных в области народных знаний составил для собирателей данных Якоб Хурт. Она была опубликована под названием «Paar palvid Eesti ärksamaile poegadele ja tütardele» (Несколько молитв для настоящих сыновей и дочерей Эстонии) в 4-м номере газеты «Olevik» в 1888 году. Он написал:

Записывать старые обычаи и традиции, так же как и старинные народные верования и суеверия очень полезно, если предварительно составить план записи материала, который необходимо собрать и записать (Hurt 1989: 50).

После этого призыва как раз и началась целенаправленная запись сообщений в области народной астрономии в различных уголках Эстонии. 10 января 1899 года Я. Хурт прочитал речь в Обществе молодых людей в приходе Святого Апостола Иоанна (Санкт-Петербург). Это был первый комплексный обзор собранного материала о народной астрономии. Сообщения, касающиеся звездного неба, Хурт получал постоянно, а позднее также отправлял их Маттиасу Йоганну Эйзену и в общества, занимающиеся сбором народных преданий.

Астрономический материал также целенаправленно и в большом количестве записывал школьный учитель К. Аллас из прихода Карья (Сааремаа), а также Й. Сыггель из Халлисте (его зачастую обвиняют в фральсификации материала) и школьный учитель Й. Сыстер из прихода Кадрина. Сыстер в своем родном регионе записал более десяти оригинальных названий созвездий. Он вообще был самым лучшим собирателем данных очень точным и компетентным. Его основным информатором была Анн Мейкар, в семье которой были моряки, и которая, вероятно, отлично запомнила школьный материал по астрономии. При этом следует отметить, что материал, связанный с народной 
астрономией, достаточно специфический. Хотя большая часть материала была собрана хорошими фольклористами, которые в то же время плохо знают звездное небо, по большей части он является практически бесполезным. При перечислении названий некоторых созвездий или в крайнем случае при уточнении значения, например, “семи звезд», получается сообщение, которое не содержит фоктической информации о созвездии или связанного с ним материала. Незначительные вариации в названиях могут быть очень важны для лингвистов или тех, кто изучает диалекты, однако в части содержания материала они являются малосущественными.

\section{2 Первичный анализ материала - Первая монография (Якоба Хурта) «Eesti astronoomia»}

Первым печатным изданием, полностью рассматривающим исключительно астрономию, является "Eesti astronomia" (Эстонская астрономия) (1899) Якоба Хурта (1839-1907), которая содержит материал, собранный в народе, разбитый на темы, к которому автор в значительной степени также добавил личные знания о народной астрономии. Уже сама структура произведения достаточно точно соответствует его программе по сбору данных и ее подразделам. Из шести глав в первой представлены верования о строении земли и неба, в т.ч. верования об облаках. Во второй главе анализируются верования, связанные с солнцем, а также времена года. Третья глава включает в себя верования, связанные с луной, наиболее важные пояснительные предания, названия лунных фраз и календарных месяцев вместе с краткими характеристиками. Таким же образом верования о луне связал с календарными месяцами Ф. И. Видеман. В четвертой главе рассматриваются солнечные и лунные затмения и связанные с ними верования. В пятой главе описываются звезды и созвездия. В ней есть общая часть и двадцать подразделов, в каждом из которых приводится название одной звезды (созвездия), пояснительные предания и верования. Также имеются небольшие звездные карты. Возле некоторых названий небесных тел имеются ссылки на античных авторов. Из числа явлений, характерных для звездного неба эстонцев, внимания заслужили так называемые puhtetäht 
и kuusulane Первое из них Якоб Хурт трактует как Марс, а относительно второго он утверждает, что речь идет о какойто блуждающей звезде. Помимо вышеперечисленного, речь также идет о т.н. своеобразных звездах, которые предсказывают особые исторические события, и о кометах. В шестой главе Якоб Хурт рассказывает об астрономических мотивах и героях, встречающихся в народном творчестве.

\subsection{0 работе по сбору данных в XX веке}

В 1927 году был создан Архив эстонского народного творчества (ERA), который сразу же в первые годы своего существования приступил к сбору дополнительных данных о религиозных верованиях эстонцев и местных традициях. Сбор данных о народном творчестве вели работники архива, отправляясь в специальные экспедиции, а затем к ним присоединились университетские стипендиаты, которых отправляли собирать данные в родные приходы. По примеру Финляндии была создана сеть местных корреспондентов (более 200 человек из различных регионов страны), которые записывали данные в своем регионе и использовали специальные методики опроса, присылаемые из Тарту. Народная астрономия входила в число тем, относительно которых имелись надежды на сбор дополнительных данных. Из числа тех, кто занимался сбором подобных данных в различных уголках Эстонии в 1930-е годы, во времена Архива эстонского народного творчества, достойны упоминания тогдашний работник ERA, а в дальнейшем литературовед Рудольф Пыльдмяэ, а также Айли Универе, которая занималась сбором диалектов на территории прихода Кодавере.

Более случайным образом сбор информации для архива сообщений, связанных с народной астрономией, продолжился также после Второй мировой войны. Материал собирался в отделе народного творчества Музея литературы им. Фр. Р. Крейцвальда и в 1949 году также в секторе народного творчества Института эстонского языка и литературы (позднее - отдел фольклористики Института эстонского языка). В 1961 году в сборнике методик проведения опросов, изданном Музеем литературы, была опубликована инструкция Пауля-Эгона Прюллера относительно сбора данных по народной астрономии (Prüller 1961), 
которая помогла собрать отдельные дополнительные данные. Специально астрономические данные редко собирались в ходе полевых работ, и по этой теме не проводилось ни одного крупного сбора данных. В незначительной степени сообщения, связанные с астрономией, также были собраны (и записаны) у носителей родственных языков, например, Энн и Тийу Эрнитс провели сбор данных среди представителей водского народа (Ernits \& Ernits 1984).

Собранные сообщения делятся на короткие ответы, пояснения и этиологические предания, а также на сказки, свободные по структуре воспоминания и простые повествовательные размышления.

\subsection{1 Критика источников}

К сожалению, тексты, собранные в архиве Эстонского литературного музея, являются неравнозначными и различаются как по содержанию, так и по качеству собранного материала. Хотя от корреспондентов народного творчества, а также от самих работников архива предполагалось, что «они поймут и осмыслят весь менталитет и мировоззрение предыдущих поколений, т.е., так сказать, систему убеждений в целом, в свете конкретных примеров, но отнюдь не будут “спасать” народ от незнания или глупых суеверий исключительно при помощи этих примеров» (Loorits 1939: 178), это далеко не всегда удава- лось. Причиной как раз и является, прежде всего, недостаточное знание звездного неба самими собирателями данных, а также случайная практика сбора данных. Поскольку сам материал им не был хорошо знаком, то ботанический, зоологический, а также астрономический материал является достаточно одноплановым, дублирующимся и поверхностным. Хотя в ходе сбора данных использовались правильные методики опроса, их не всегда удавалось придерживаться, и по этой причине полученный материал не отображает полностью реальную ситуацию, а также является неравномерным, что в свою очередь усложняет, например, использование некоторых математических методов анализа.

Зачастую собирались, прежде всего запомнившиеся высказывания, воспоминания, рассказы. Часто причиной достаточной 
поверхностности является то обстоятельство, что собиратель данных пришел в гости к пожилому человеку на пару часов, в течение которых на бумагу записывались лучше всего запомнившиеся сообщения. Большинство материала было записано летом, при дневном свете, когда реальное звездное небо практически не наблюдалась. Еще П.-Е. Прюллер отметил:

В некоторых случаях на основании лишь архивного материала сложно только по названию созвездия точно определить соответствующий объект на небесном своде, т.к. данные о звездном небе были собраны преимущественно в дневное время без проверки в вечернее время на звездном небе (Prüller 1968: 18).

\section{3. Обзор и структура собранного материала}

В одном лишь отделе Эстонского литературного музея - в фольклорном архиве эстонского народного творчества - хранится около 1,5 млн страниц устных преданий эстонцев, собранных преимущественно в течение последних 150 лет. Сообщений, напрямую связанных с народной астрономией, насчитывается около 9000. Кроме того, соответствующий материал имеется еще в некоторых разделах, связанных с календарными знаменательными датами и практическим ведением хозяйства. Разделение корпуса текстох, связанного со звездами, по содержанию иллюстрирует следующий рисунок. Поскольку составители картотеки четко разделяли Млечный путь и хвостатые звезды, они не включены в эту совокупность, а падающие звезды и планеты представлены в этом корпусе хаотически, и поэтому они также включены в статистику.

В общей сложности на рисунке 1 в анализируемом корпусе представлено около 1400 сообщений. Как мы видим, сообщений о падающих звездах даже больше, чем об одиночных звездах и созвездиях. Раздел «общее» представлен по большей части в виде перечня названий какой-либо звезды или созвездия, и часто эти названия дублируют сообщения, перечисленные в столбце «созвездия и названия звезд». Основной целью изучения звездного неба является предсказание погоды, в то время как прочие функции, например, время, календарь, ориентация и т.д., отходят на второй план. В связи с падающими звездами су- 


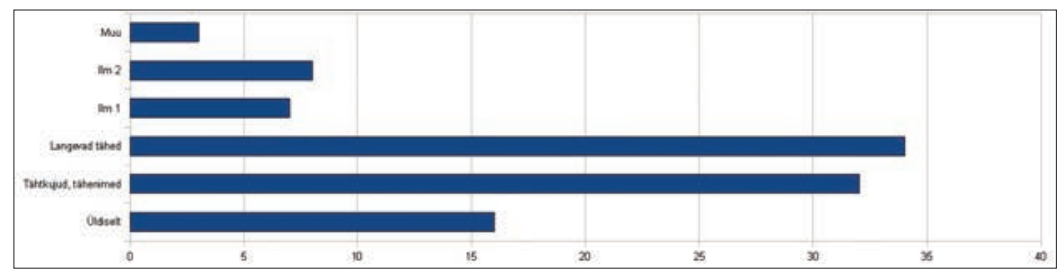

Рисунок 1. Разделения сообщений в анализируемом корпусе (\%). Сверху: другие, погода 1, погода 2, падающие звезды, созвездия и названия звезд, общее.

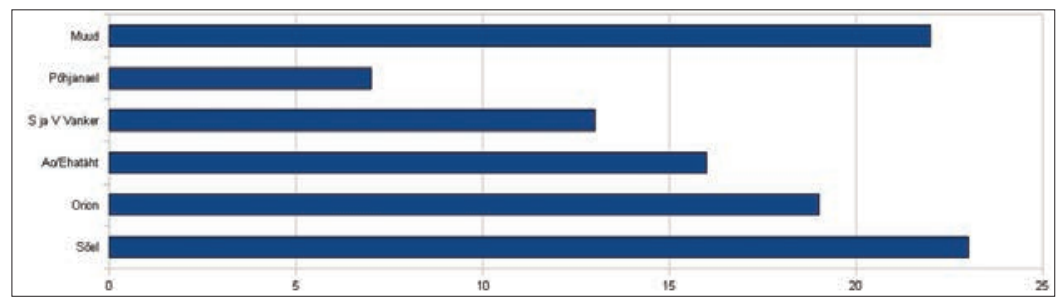

Рисунок 2. Разделения сообщений о созвездиях и названиях звезд (\%). Сверху:другие, Полярная звезда, Большая и Малая Медведица, Венера, Орион, Сито.

ществует поверье, что нужно загадать желание. Распределение материала в столбце «созвездия и названия звезд» представлено на другой диаграмме. Как мы видим, больше всего информации о Сите, затем следуют Орион и Венера. (Здесь и далее курсивом пишутся названия из классической астрономии). Полярная звезда и Большая Медведица должны быть известны не менее хорошо, но данных о них значительно меньше. Здесь, вероятно, сказалось субъективное отношение лиц, занимающихся сбором данных. Данные записаны достаточно произвольно, а сведений о созвездиях, которые для исследователей, занимающихся сбором материала, являлись достаточно обычными, вообе нет. Вероятно, все аналогичные сборники данных страдают от подобной неравномерности, и по этой причине, давая какую-либо оценку, сложно использовать простые общие методы, и к каждому объекту исследования следует подходить индивидуально. Исходя 
из вышеизложенного, особую важность, скорее, представляют корректные отдельные данные, но их в собранном материале крайне мало (лишь небольшой процент). Такими отдельными данными являются, например, надлежащим образом собранные записи о созвездиях и названиях звезд в Палмсе, которых в других уголках Эстонии обнаружено не было. Такие данные, конечно же, легко можно принять за выдумки или фральсификации, однако, с другой стороны, они хорошо задокументированы, прекрасно ложатся на реальное звездное небо (что само по себе не исключает возможность фральсификации), и логика их названий указывает на более ранние наслоения, от которых практически ничего не осталось.

\section{4. Публикации}

Студент Роберт Ливляндер, будущий работник Тартуской обсерватории, в начале 1920-х годов посетил Сааремаа и по собственной инициативе провел опрос, связанный с тем, как в народе воспринимается небесный свод. Основанием послужила народная астрономия Я. Хурта, однако в ходе обобщения результатов ему удалось сделать несколько важных наблюдений. Наиболее важным из них является тот фракт, что его информаторы не знали крупных созвездий, например, в Большой Медведице каждая звезда рассматривается отдельно, а не в виде единого целого, созвездие Лебедь, или Северный Крест, в народе неизвестно, в то время как созвездие Дельббин, или Ноев Ковчег, известно очень хорошо (Livländer 1923). Хотя этот опрос можно охарактеризовать как относительно случайный, его также можно рассматривать в качестве повторной попытки того, что Я. Хурт пытался сделать в книге «Eesti Astronomia», в результате чего автор отмечает, что знание звездного неба существенно ухудшилось. Также его статья представляет собой относительно комплексный обзор знания звездного неба среди жителей Сааремаа, а наблюдение относительно плохого знания созвездий указывает на первобытность их знаний.

Особенностью фольклорных исследований начала XX века являются обзоры народных верований эстонцев, представленные различными исследователями. Стимулирующими фракторами послужило, с одной стороны, создание университета 
на базе эстонского языка и необходимость в обзорном подходе, a с другой стороны - отсутствие более современных отдельных исследований и подходов, основанных на аутентичном народном материале.

Здесь можно упомянуть книгу религиоведа и фольклориста Маттиаса Йоганна Эйзена «Maа päält taevasse. Arutlused päikese, kuu, tähtede ja ilma eluavalduste kohto» (От Земли до неба. Рассуждения о солнце, Луне, звездах и мироустройстве) (Eisen 1909) (1857-1934), изданную в 1909 году. Она содержит достаточно подробное рассмотрение таких мифологических героев, как небесные женихи, сын Солнца, дева света. В этой книге также многократно упоминается свободная переработка мифологического материала Фр. Р. Фельманом и Фр. Р. Крейцвальдом.

Сводные данные о народной астрономии, особенно о представлениях о космосе и общем создании мира, также можно найти и в более поздних произведениях М. Й. Эйзена. «Eesti vana usk. Eesti mütoloogia IV» (Старая религия Эстонии. Эстонская мифология) (1926) представляет собой антологическую подборку народных верований, из числа которых автор на свой вкус выбрал те или иные и включил в свою книгу. В качестве подтем внимания заслуживают создание мира, небо, Солнце, Луна, звезды. В общей части приводятся сравнения «Калевалы», финских рунических песен и германской мифологии (в основном на основе работ братьев Гримм). И снова используются более ранние печатные издания, аутентичный материал представлен вперемешку с псевдомифологией и неаутентичными текстами.

Более подробное изучение религиозных верований представил Оскар Лооритс (1900-1961), в более ранних исследованиях которого материала, связанного с астрономией, достаточно мало. Он также подробно рассматривает космогонический материал в своем крупном произведении из трех частей под названием «Grundzüge des estnischen Volksglaubens» (Loorits 1949, 1951, 1957), в котором особенно ценными являются данные о связи между представлениями о душе, мировой организации и астрономическими верованиями. Также О. Лооритс подробно изучил, например, северное сияние, которое имеет очень интересное мифологическое объяснение в эстонской религии, и в связи с которым сохранилось множество архаических повествовательных мотивов (Loorits 1949: 281-289). Кроме того, он проанализировал в дополненном формате представление эстонцев о звездном 
небе (основанное на трактовке Якоба Хурта, но с учетом более поздних данных, собранных в народе) и верования о созвездиях и планетах. Отдельно и более подробно, чем раньше, рассмотрена связь между лунными фразами и магическими обрядами и работами, а также распространение терминологии, с лунными фазами, на территории Эстонии. О. Лооритс одним из первых подробно охарактеризовал культ луны, распространенный среди эстонцев, и представил его как достаточно запутанный и многогранный феномен (Loorits 1957: 452). Культ солнца он считает типичным, скорее, для индоевропейских народов (Loorits 1957: 450) и ссылается на несколько мотивов, распространенных в мифологических преданиях некоторых европейских народов, которые в Эстонии неизвестны: солнечные суда, солнечный щит и т.п. Также подробно рассмотрены предания, связанные с небом и его обитателями (Loorits 1949: $349 \mathrm{ff}, 387 \mathrm{ff}$ ), и мифические реликты, отображенные в рунических песнях. В то же время он ссылается на связь между небесными явлениями и судьбой человека. По своему исследовательскому методу О. Лооритс, прежде всего, специалист в компаративном религиоведении, и по этой причине, наряду с рассматриваемыми явлениями, он также приводит сравнительные данные по преданиям германских, славянских и прочих контактных языковых групп.

Являясь представителем феноменологической школы, Ивар Паульсон (1922-1966) в подразделе своего произведения «Vana Eesti rahvausk. Usundiloolisi esseid» (Давнее эстонское народное верование. Религиоведческое эссе) (Paulson 1966) «О земле и о мире» рассматривает веру в небо, небесного отца, Тара и основы грозового культа; он не исследовал непосредственно касающиеся астрономии френомены. Однако этими вопросами (и снова лишь мимолетно) он занимался в обзорных статьях, касающихся различных народов северной Евразии.

Паульсон сделал исключительно хороший обзор исследований, касающихся народов северной Евразии, поэтому понятно, что его внимания заслужили, помимо природных духов и представлений о душе, также концепции неба и земли и различные погодные и небесные божества.

Конспект лекций теолога и религиоведа Уку Масинга (19091985) «Eesti usund» (Эстонское верование) поступил в печать лишь в 1995 году (Masing 1995). Цикл лекций был подготовлен 
уже в 1930-1940-х годах и за долгое время распространился среди любителей данной тематики в виде печатных копий. Трактовка Масинга является немного конспективной. При составлении лекций он использовал много параллелей с финской культурой, взятых, главным образом, из издания финских рунических песен «Suomen kansan vanhat runot» (Старинные песни финского народа). Также представлены точки зрения Уно Харва, Каарле Крохна и других финских религиоведов. Что касается Эстонии, Масинг основывается не на материалах архива, а на более ранних публикациях. Таким образом, его источниками являлись Фр. Р. Крейцвальд и Фр. П. Фельман, балтийские немцы Й. В. ф. Люце с Сааремаа и Ф. И. Видеман. В главе «Погода и погодные явления» рассказывается о космогонии, небесах, солнце, луне, звездах, северном сиянии, а также о небесных девах, небесном божестве Ильмарине, Лемминге, Виббоане и метеорологических явлениях. Из перечисленного выше уже становится понятно, что в своих лекциях Масинг подробно рассказывал о псевдомифологических персонажах и творчестве литераторов XIX века. Эстонский материал представлен в этом конспекте преимущественно в виде пересказов текстов преданий.

\section{1 Вторая монография (Пауля-Эгона Прюллера)}

Второе специальное исследование эстонской народной астрономии было проведено в 1968 году, его составителем является Пауль-Эгон Прюллер (1905-1979). Суть в том, что он составил программу опроса, используя опубликованные ранее различные варианты (Prüller 1961a; Prüller 1961b; Prüller 1962; Prjuller 1966), в результате чего получился достаточно подробный обзор (Prüller 1968) - 58-страничное издание с кратким содержанием на русском, немецком и английском языках. Основными частями краткой монографии является обзор источников и данных; мир древних эстонцев (звезды, Луна и Солнце); созвездия и их отображение в народном творчестве; а также отображение народной астрономии в современной литературе. Основной темой исследования являются эстонские названия звезд и созвездий в эстоноязычных печатных и рукописных произведениях XVII 
и XVIII веков, а также определение звезд и созвездий, известных древним эстонцам и записанных более поздними собирателями.

П.-Э. Прюллер тщательно искал материал в более ранних рукописях и изучил материал, собранный в картотеке народной астрономии после Хурта. Произведение Прюллера является достаточно подробным в части названий звезд и созвездий и разъяснения их происхождения. Указываются источники названий созвездий, а также связанные с ними фразеологические обороты и пересказы известных разъяснительных и этиологических преданий. Как правило, он не приводит данные об известности или исключительности самих текстов, связанных с народным творчеством.

У него также рассматриваются особенности прагматического познания звездного неба: предсказания погоды, определение времени и направления с помощью звезд, связи небесных объектов с посевным календарем и т.п. Достаточно мало говорится о своеобразных звездах и кометах. К сожалению, Прюллер, как и частично М. Й. Эйзен, вместо народного творчества сосредоточил все свое внимание на «Калевипоэге» и случайных примерах из песен. Эйзен в своих изданиях отметил фактическую удаленность «Калевипоэга» от народного творчества (Eisen 1909), хотя П.-Э. Прюллер относился к нему как к аутентичному материалу.

Конечно, ощущается, что некоторые исследования в области религии (например, О. Лооритс) не были доступны ему во время написания работы, и поэтому трактовка материала получилась несколько практично-материалистичной. Толкования мифов он избегал. В незначительной степени приводятся ссылки на финские и русские работы, при этом именно под влиянием первых в исследовании появились интересные выводы о возрасте названий созвездий и способах определения времени. Он добавил названия еще двенадцати созвездий к пятнадцати названиям созвездий и звезд, перечисленным в работе Я. Хурта.

И все же можно было как с помощью новейших записей, так и картотеки диалектов Общества родного языка найти еще кое-какие названия созвездий, а также позднейшие сообщения о преданиях. Но лишь оцифровка всего обширного архива народного творчества и сохранившихся архивов диалектных текстов давала возможность получить наиболее подробный обзор народной астрономии. 
Анализ астральной мифологии, проходящей сквозной нитью в связанных с религией сообщениях и более обширных текстах, требует времени и крупномасштабной предварительной работы, в том числе наличия достаточного количества описательных и сравнительных исследований. Поэтому, как правило, ограничивались статьями и единичными исследованиями. Авторами большинства из них являлись профессиональные астрономы, обратившиеся к мифологии и фольклору из интереса к отображению интересующего их предмета в культуре.

Монография П.-Э. Прюллера имеет важное значение для данной темы, т.к. составленная им звездная карта народной астрономии многократно публиковалась как репрезентирующая аутентичный материал. На самом же деле на небесную карту нанесены названия созвездий, полученные из сообщений, собранных в разных регионах, а критерий отбора вариантов был следующий: выбирались наиболее эфректные и созвучные между собой названия, заметно стремление максимально охватить созвездия при картографировании.

Работу П.-Э. Прюллера, по составлению исторических обзоров и трактовок, продолжил Хейно Ээльсалу (1930-1998), в научно-исторических статьях которого много- кратно упоминаются также исследования народной астрономии (Eelsalu 1975: 72-74), однако он все же не очень далеко ушел от Прюллера - добавил несколько новых авторов, но не охарактеризовал подробно их публикации. Причиной, очевидно, является, прежде всего, особый интерес, который Ээльсалу испытывал к проблемам археоастрономии (или палеоастрономии), и он рассматривает материал, прежде всего, с этой точки зрения.

\section{2 Статьи, связанные с народной (популярной) астрономией}

В статье «Tähistaeval põhinevatest uskumustest» (Верования на основе Звездного неба) Энн Касак разделил тексты, связанные с народной астрономией, на четыре большие группы: космологические, космогонические, метеорологические и астрологические верования. Автор приводит множество примеров и ссылается на международный характер материала (Kasak 1996, 1999). 
Позднее интерес Э. Касака сосредоточился преимущественно на древней астрономии, прежде всего на старых названиях планет Месопотамии и их связях с божествами (Kasak 2000), на несовместимости научной картины мира и астрологии на ранней истории астрологии (Kasak \& Veede 2000).

Статья Тыну Тувикене «Marsi kanalite ajalugu» (История марсианских каналов) (Tuvikene 1998: 49-55) рассказывает о важном религиоведческом акте - о том, как астрономы воспринимали и заносили на карту Марса каналы, и как бизнесмен и литератор П. Лоуелл популяризировал их в конце XIX - начале XX века. Публикации Лоуелла имели настолько большой успех в народе, что этот случай нашел широкое отображение в культуре: каналы Марса и верования в возможность жизни на Марсе стали обыденными. Они становились сюжетами для художественных и литературных произведений и франтастических рассказов.

Относительно каналов Марса речь шла об очень ощутимом влиянии пишущей прессы на народные верования. Аналогичными в некотором смысле являются также предания, связанные с кометами. Эрик Таго в работе «Sabatähed, mis tegid ajalugu» (Кометы, которые сделали историю) (Тago 1997) рассматривает связанные с кометами предания и рассказывает о наиболее известных в истории пророческих кометах. Как фольклористка Маре Кыйва, прежде всего, изучала изменения в преданиях о кометах на протяжении столетий и их связь с преданиями о конце света. В частности, у нее подробно рассматривается предсказание пророка Юхана Лейнберга о комете как предвестнице конца дней человеческих и реакции в народе (Kõiva 2001).

Андрес Куперьянов составил обзор эстонских названий звезд и верований, связанных с Млечным путем, а также их толкований, различая шесть типов преданий. В произведении «Тӓһеопи» рассказывается об эстонских сельских обсерваториях, уникальной модели солнечной системы, созданной Хуго Раудсааром, а также дается представление о жизни и работе ее создателя в качестве ученого. В журнале "Vaatleja» (Наблюдатель) была опубликована серия статей об отдельных созвездиях вместе с картой соответствующего созвездия, их названиями и связанными с ними основными преданиями и верованиями (Kuperjanov 2000a, 2000b, 2000c). 
Прежде всего, исследователи, начиная с упомянутого выше Оскара Лооритса, связывали рунические песни и их мотивы с тем, что происходит в звездном небе, а также с мифами (или же с повседневной реальностью?). В конце 1960-х - начале 1970-х годов были составлены толкования многих рунических песен, в которых также присутствует астрономическое измерение. Противоположными по своей сути являются, например, толкования песни «Tӓhemõrsja» (Невеста звезды) Эдуардом Роозом (Roos 1969), который изучал отображение повседневной реальности, и Яаном Каплински (Kaplinski 1970), который придерживался точки зрения, что в песне присутствуют мифические реликты. Аадо Линтроп в своей работе «Suur tamm ja õde-vendo» (Великий дуб и брат с сестрой) (Lintrop 2000) рассматривал связь образа дуба с мировым деревом.

Международные легенды, связанные со звездами и созвездиями, кратко представлены в составленном астрономами Яаком Яанисте и Энном Сааром атласе «Täheatlas» (Атлас звезд) (Jaaniste \& Saar 1990). Также в атласе имеется карта звездного неба Эстонии и ее описание. Аналогичная карта также использована на большой карте неба в Тартуской обсерватории. В каталоге Тоомаса Ааса и Пеэпа Кальва "Eesti taevaatlas» (Эстонский атлас неба) к классическим названиям созвездий также добавлены псевдомифологические и народные названия, перечисленные А. Гренштейном (Aas \& Kalv 2000).

\section{5. Об археоастрономии в Эстонии}

\section{1 Хейно Ээльсалу}

С середины 1970-х годов в связи с новым периодом национального пробуждения, поисками в сфере национальной истории и идентичности народная астрономия и, в частности, народное времяисчисление, а также археоастрономия предстают в абсолютно неожиданном и интересном свете. Ключевые личности этого движения существенно повлияли на общее интеллектуальное развитие эстонского общества. В области астрономии центральной фригурой был астроном и историк науки Хейно Ээльсалу. В начале 1970-х годов его исследовательский интерес 
был направлен на места жертвоприношений, исследование камней с искусственными выемками, календарную проблематику и все чаще на толкование мифов в свете палеоастрономии (термин Ээльсалу, в международном контексте больше используется определение археоастрономия), это отразилось в десятках статей, которые вышли в 1978-1996-х годах. В первых публикациях он рассматривает древности каменного века и пытается понять их связь со звездным небом. ${ }^{1}$ Позже возникли исследования на календарные темы, они появлялись на протяжении нескольких десятков лет. ${ }^{2}$ Во всех этих работах сквозит интерес к связям между звездным небом и мировоззрением древних людей.

Рассуждения Х. Ээльсалу опирались на итоги междисциплинарных конференций по палеоастрономии и прочим палеонаучным дисциплинам, проходивших в 1979 году. Конференции освежили религиозные и мифологические знания и собрали несколько сотен любителей данной тематики. С докладами выступили люди, глубоко заинтересованные в исследовании дней минувших и их своеобразных и гипотетических толкованиях. ${ }^{3}$

В конце 1970-х годов на первый план вышло еще одно плодотворное направление по увековечиванию и толкованию архаичной культуры - исследование наскального искусства. Первая состоящая из эстоноземельцев экспедиция на место обнаружения наскальных рисунков в районе Онежского озера была организована в 1978 году под руководством Кальо Пыллу (Eelsalu 1993: 1688). С 1982 года по сегодняшний день увековечивание наскальной живописи продолжают энтузиасты из Эстонии, России и Финляндии под эгидой Эстонского общества древних рисунков и Вяйно Пойкалайнена (Poikalainen \& Ernits 1998: 25 jj). Толкованием находок, в т.ч. поиском взаимосвязей между обнаруженным материалом, народным творчеством и астрономическими знаниями, помимо Хейно Ээльсалу ${ }^{4}$, также занимались Энн Эрнитс, Вяйно Пойкалайнен, Пеэтер Теньес и другие участники экспедиций, организованных Эстонским обществом древних рисунков (см., например, Poikalainen \& Ernits 1987). Вероятно, также по той причине, что әстонские ученые были настроены достаточно скептически в отношении палеоастрономических толкований, в 1980 году исследовательский интерес Ээльсалу сместился в направлении балтийского фольклора. На протяжении пары десятков лет Х. Ээльсалу также 
занимался толкованием мифов, изучая их возраст и проецируя их мотивы на звездное небо. ${ }^{5}$

Все эти статьи и форумы, прежде всего именно статьи Хейно Ээльсалу, поспособствовали тому, что с астральной мифологией и археоастрономией хорошо знакомы несколько поколений эстонцев. Свои взгляды он изложил в несколько более сухом тоне в книге «Ajastult ajastule» (От эпохи к эпохе) (Eelsalu 1985), которая была издана в 1985 году. И все же наибольший интерес и отклик у читателей вызвали статьи, опубликованные в «Eesti Loodus» (Эстонская природа), «Keel ja Kirjandus» (Язык и литература) и «Looming» (Творчество).

Ээльсалу был продуктивным и последовательным реконструктором архаического звездного неба, он связывал звездное небо с мотивами рунических песен и мифов. Недостатком гипотез, основанных на представленных в его статьях точных вычислениях, является то обстоятельство, что возраст мотивов из различных мифов невозможно точно датировать. Краткосрочность социальной памяти и то обстоятельство, что современную логику, верования и познавательные пояснения невозможно однозначно применить в отношении жителей местных земель, обитавших здесь тысячи лет назад, заставляет сомневаться в его конструкциях. Их принципиальная ценность, однако, заключается во взаимосвязи эстонских базовых мифов с такими явлениями в истории Эстонии, как древнее искусство и археология. Кроме того, его произведения донесли до современного человека понимание того, как древние люди воспринимали небесный свод и созвездия.

\section{6. Об исследованиях в области народной астрономии в XXI веке}

Отдел фольклористики Эстонского литературного музея в качестве одного из направлений своей работы видит исследование народных знаний. На данный момент охвачены исследованиями этноботаника, этномедицина, этноастрономия, а также сферы, связанные с религиозной археологией. В области народной астрономии при поддержке различных проектов осуществляется ввод в пользование текстов с астрономическим содержанием 
из различных собраний. По состоянию на май 2014 года, было использовано 15100 статей с полными текстами из 13 различных собраний. Рисунки 3 и 4 представляют обзор разделения введенного материала в четырех крупнейших собраниях (H,1860-1906; E, 1880-1934; ERA, 1927-1944; RKM, 1945-1996). В рамках темы исследования были изданы статьи Маре Кыйва и Андреса Куперьянова.

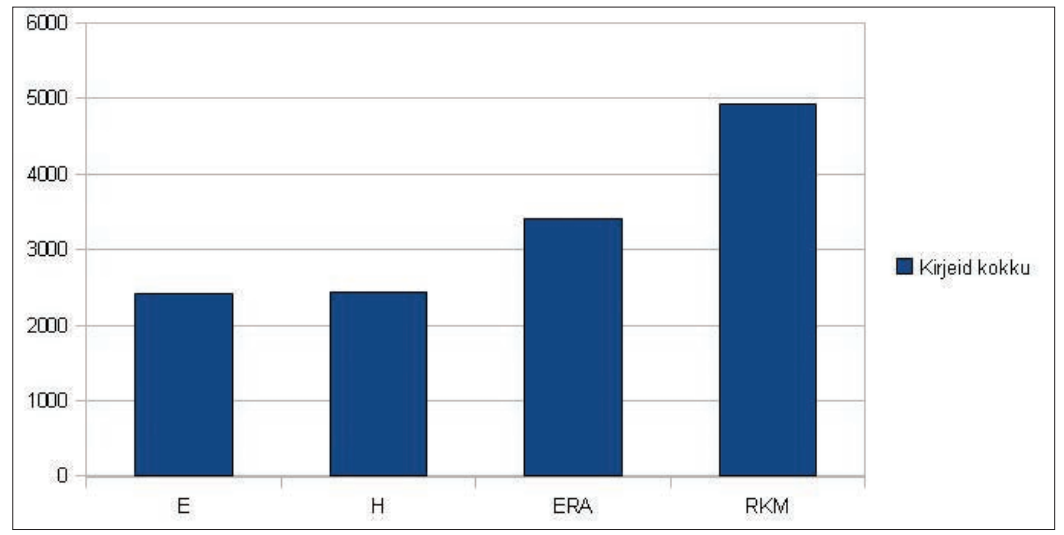

Рисунок 3 . Количество введенного материала в четырех крупнейших собраниях.

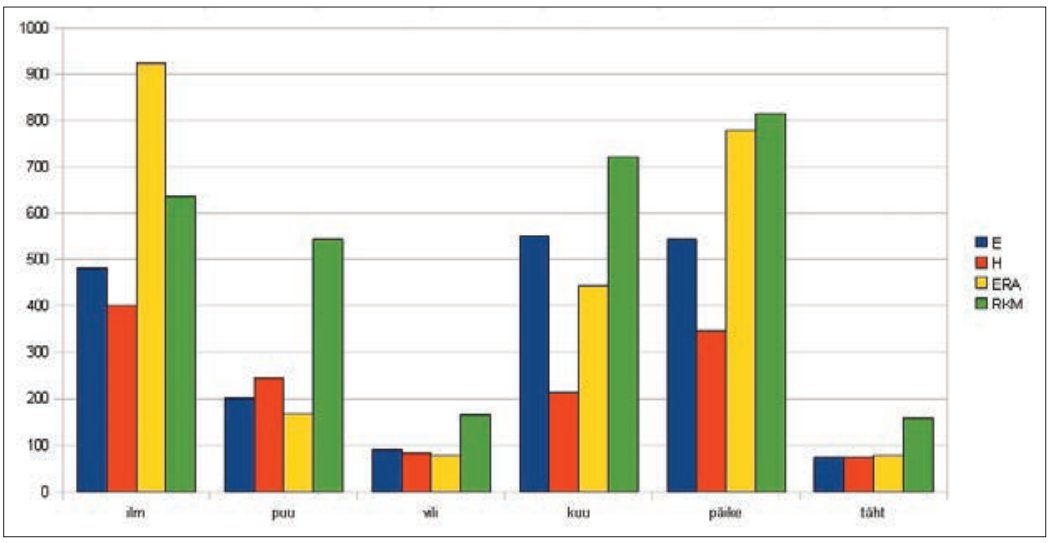

Рисунок 4. Разделения введенного материала в четырех крупнейших собраниях. От левого: погода, дерево, злаки, Луна, Солнце, звезда. 


\section{1 Третья монография (Андреса Куперьянова)}

В 2003 году была издана третья монография по теме народной астрономии под названием «Eesti Taevas. Uskumusi ja tõlgendusi» (Эстонское небо. Исследования и интерпретации) (Kuperjanov 2003), которая по своей структуре близка к двум предыдущим. Монография опиралась прежде всего на рукописный материал из области народной астрономии, а также на информацию, опубликованную в предыдущих исследованиях. Особенность монографии в диахроническом и синхронном анализе религиозного материала, в ней также представлен обзор названий звезд и астрономических явлений, отображенных в поэтической лексике фольклора. Также была классифицирована информация, связанная с повседневной магической и религиозной практикой (влияние лунных фаз на различные сферы жизни). Некоторые темы уточнялись в более поздних статьях, поскольку появились дополнительные возможности значительно расширить глобальный контекст, используя в работе материалы, которые ранее были недоступны, а теперь, благодаря различным проектам по оцифровке, находятся в открытом доступе.

\section{2 Конференция SEAC в Тарту}

В рамках данной темы в отделе были проведены две конференции: 1 марта 2004 года под названием «Eesti taevas. Erinevaid vaatenurki» (Эстонское небо. Различные перспективы) (http://www.folklore.ee/rl/fo/konve/konv.html) и 22-23 мая 2008 года - «Eesti Taevas II. Aeg ja ruum» (http://www.folklore.ee/rl/ fo/konve/2008/taevas2). Важным мероприятием в 2002 году, связанным с археоастрономией, стала международная конференция SEAC (Европейское общество астрономии в культуре), организованная Тартуской обсерваторией и отделом фольклористики Эстонского литературного музея, на тему космических катастроф и их отображения в культуре. Основными организаторами конференции стали Изольд Пустыльник и Маре Кыйва, с материалами можно ознакомиться по адресу www. folklore.ee/SEAC. В сборнике докладов конференции «Cosmic Catastrophies» опубликованы статьи 36 авторов, и 5 из них - 
эстонских исследователей (Kõiva et al. 2005). Сборник позволил ввести эстонский материал и исследовательскую работу в сравнительный европейский дискурс.

\section{3 Статьи в области этно- и археоастрономии}

Помимо отдельных статей, в предварительно рецензируемых научных изданиях "Folklore: Electronic Journal of Folklore» (http://www.folklore.ee) и «Mäetagused» (http://www.folklore.ee/ tagused) было опубликовано несколько специальных номеров на археоастрономическую тематику (F: EJF 31, 32, 44; MT 30, 46, 48), в которых рассматривались астрономические и астральномифологические предания разных народов. Авторами являлись Ниссабай Бекбассар, Юрий Березкин, Наталья Дмитриева, Матей Горшич, Александр Гура, Энн Эрнитс, Яак Яанисте, Роомет Якапи, Тынно Йонукс, Эве Кикас, Весселина Колева, Тармо Кульмар, Андрес Куперьянов, Маре Кыйва, Йиржи Мареш, Леонид Марсадолов, Мирьям Менсей, Андрей Плетерский, Елена Попова, Барбара Раппенглюк и др., Виталий Ромейко, Юло Сийметс, Николай Сивков, Йонас Вайшкунас и Аста Ыйм.

Во многих статьях также рассматриваются междисциплинарные темы, такие как мир в представлении детей, названия небесных объектов, лунные пятна, способы измерения времени, археоастрономические объекты и т.д., в т.ч. трактовка конца света. Журналы можно найти в Интернете и, помимо авторов, печатающих статьи в специальных номерах, отдельные статьи на данную тематику также публиковали Энн Касак, Ниёле Лауринкене, Аадо Линтроп, Эрик Таго, Тыну Тувикене, Тыну Юлемаанте.

В 2009 году в рамках Международного года астрономии прошла конференция под названием "Дни Крейцвальда", организованная Эстонским музеем литературы, а в 2012 году в серии ежегодников "Paar Sammukest» были изданы статьи, подготовленные на основе докладов конференции. Авторами являются Юрий Березкин, Яан Эйнасто, Энн и Тийу Эрнитс, Пеэтер Эспак, Малль Хийемяэ, Райво Калле и Рената Сыуканд, Ынне Кепп, Андрес Куперьянов, Маре Кыйва и Аадо Линтроп. 
Тематика очень обширная: космология темного вещества, народная астрономия, ранняя астрономия Среднего Востока и т.д. Книгу с полными текстами можно прочитать по адресу: http:// www.folklore.ee/rl/pubte/ee/araamat/2009/sisu.htm (Kõiva et al. 2012). В 2010 году, например, вышел журнал «Folklore: Electronic Journal of Folklore», 44-й выпуск, и его параллельный эстонский номер «Mäetagused» 46, содержащий несколько тематических статей.

\section{Выражение благодарности}

Работа над статьёй осуществлена при поддержке Министерства образования и науки Эстонии (институциональный исследовательский грант IUT 22-5) и Фонда регионального развития EC (Центр компетенции по Эстонским исследованиям CEES TK 145).

\section{Примечания}

1 Eelsalu 1975; Eelsalu \& Hamel 1980; Eelsalu 1982.

2 Eelsalu 1976 a, 1976 b; Eelsalu \& Ernits 1977; Eelsalu \& Ernits 1978; Eelsalu 1979; Eelsalu 1987; Eelsalu 1994; Eelsalu 1997.

3 Более подробно о трех конференциях Viluoja 1979, 1981; Salve 1983; Kõiva 1983; Eelsalu 1993 jj.

${ }^{4}$ Eelsalu 1989: 111-113; Eelsalu 1990: 316-317; Eelsalu 1993: 165-170.

5 Eelsalu 1980: 12, 785-787; Eelsalu 1983: 2, 113-115; Eelsalu \& Stöör 1984: 3, 156-158; Eelsalu 1986: 3, 167-168; Eelsalu 1987a: 1, 38-40; Eelsalu 1988: 2, 110-111; Eelsalu 1991: 1/2, 34-35; Eelsalu 1991a: 8, 489-490 и др. 


\section{Литература}

Aas, Toomas \& Kalv, Peep 2000. Eesti Taevaatlas. [Эстонский атлас неба.] Tallinn: Rein Veskimäe.

Clare, Johann Christoph 1734. Cellarius Esthonico-Germanicus oder Wörterbuch der Ehstnischen Sprache. Рукопись находится в Эстонском архиве истории культуры при Эстонском литературном музее.

Eelsalu, Heino 1975. Astroarheoloogia postuumne tunnustus kiviaja taeva-vaatlejatele. Eesti Loodus 2, cc. 73-78.

Eelsalu, Heino 1976. Astronoomia areng Eestis kultuuriloolise probleemina. Teaduse ajaloo lehekülgi Eestist II: Kogumik. Tallinn: Valgus, cc. 319-323.

Eelsalu, Heino 1976a. Kalendrikorralduse põhietapid. Eesti Loodus 5, cc. 319-323.

Eelsalu, Heino 1976b. Missugune oli meie esivanemate päikesekalender ja millal ta kujunes? Eesti Loodus 12, cc. 796-798.

Eelsalu, Heino 1979. Talihari ja Linnutee. Keel ja Kirjandus 4, cc. 226-228. Eelsalu, Heino 1980. Sampo mõistatuse loodusloolised võtmed. Eesti Loodus 12, cc. 785-787.

Eelsalu, Heino 1982. ...ja tehislohkudega kivide otstarbest üldse. Eesti Loodus 5, c. 319.

Eelsalu, Heino 1983. Jääaeg ja mõistatuslik Sõnn. Eesti Loodus 2, cc. $113-115$.

Eelsalu, Heino 1985. Ajastult ajastule. Tallinn: Valgus.

Eelsalu, Heino 1986. Andromeeda tähtkuju kiviaja vaatlusprotokollides. Eesti Loodus 3, cc. 167-168.

Eelsalu, Heino 1987. Kalendrilt kalendrile. Keel ja Kirjandus 11, cc. 663666.

Eelsalu, Heino 1987a. Planeet Veenus muinasvaatlejate protokollides. Eesti Loodus 1, cc. 38-40.

Eelsalu, Heino 1988. Ekliptika ja esivanemad. Eesti Loodus 2, cc. 110-111. 
Eelsalu, Heino 1989. Põhjala kaljumaalingud ja tähekalender. Eesti Loodus 2, cc. 111-113.

Eelsalu, Heino 1990. Kaljuraiendite lindude mõistatus. Eesti Loodus 5, cc. $316-317$.

Eelsalu, Heino 1991. Tulemärk ja Põlvitaja ajastu. Eesti Loodus 1/2, cc. $34-35$.

Eelsalu, Heino 1991a. Koit ja Hämarik ning tanabata-õhtu. Keel ja Kirjandus 8, cc. 489-490.

Eelsalu, Heino 1993. Sõnumilt sõnumile: Meenutusi ja hinnanguid: Paleokultuuri uurimine Eestis 1960-80ndail. Looming 12, cc. 16811690.

Eelsalu, Heino 1994. Ürgse kuukalendri asümmeetriline duaaljaotus. Keel ja Kirjandus 4, cc. 225-228.

Eelsalu, Heino 1997. Tähtpäevakalendri vanim kihistus kui süsteem: Päikesekalender. Keel ja Kirjandus 11, cc. 762-768.

Eelsalu, Heino \& Ernits, Enn 1977. Mida aimame esivanemate kuukalendrist. Eesti Loodus 12, cc. 779-781.

Eelsalu, Heino \& Ernits, Enn 1978. Keeleandmed soome-ugri varase kalendriloo pidepunktidena. Keel ja Kirjandus 5, cc. 280-282.

Eelsalu, Heino \& Hamel, Jürgen 1980. Väikeste tehislohkudega kivid ja paleo-astronoomia. Eesti Loodus 6, cc. 379-381.

Eelsalu, Heino \& Stöör, Ülo 1984. Looduse värvid ja loomise lugu. Eesti Loodus 3, cc. 156-158.

Eisen, Matthias Johann 1909. Maa päält taevasse: Arutlused päikese, kuu, tähtede ja ilma eluavalduste kohta. [От Земли до неба. Рассуждения о солнце, Луне, звездах и мироустройстве.] Tartu: Hermann.

Eisen, Matthias Johann 1919. Eesti mütoloogia. [Эстонская мифология.] Tallinn: Eestimaa Kooliõpetajate Vastastiku Abiandmise Seltsi raamatukauplus.

Gildemann, Berend 1849 (издатель). Mailma made õppetus: Isseärranis Ma rahva koolmeistritele ja kolide tarwis. [Учение о странах мира. Специально для учителей сельских школ.] Pernau: [s.n]. 
Grenzstein, Ado 1885. Taeva-kaart. [Карта неба.] Oleviku 50 (1885) II hinnata erilisa. Tartu: [s.n.].

Göseken, Heinrich 1660. Manuductio ad Linguam Oesthonicam = Anführung zur Öhstnischen Sprache. Reval.

Helle, Antor Thor 1732. Kurtzgefasste Anweisung zur ehstnischen Sprache, in welcher mithetheilet werden I. Eine Grammatica, II. Ein Vocabularium, III. Proverbia, IV. Aenigmata, V. Colloquia. Halle: [s.n.].

Hupel, August Wilhelm 1774-1782 (сост.). Topographische Nachrichten von Lief- und Ehstland 1-3. Riga: Johann Friedrich Hartknoch.

Hupel, August Wilhelm 1780. Ehstnische Sprachlehre für Beide Hauptdialekte, den revalschen und dörptschen, nebst einem vollständigen Wörterbuch. Riga \& Leipzig: Hartknoch.

Hurt, Jakob 1963. Paar palvid eesti ärksamaile poegadele ja tütardele. Eduard Laugaste. Eesti rahvaluuleteaduse ajalugu: Valitud tekste ja pilte. Tallinn: Eesti Riiklik Kirjastus, cc. 202-210. (Allikas: Olevik 1888.)

Hurt, Jakob 1989. Eesti astronomia. Kõne Eesti Jaani koguduse Noortemeeste Seltsis 10. Jaanuaril 1899. Jakob Hurt. Mida rahvamälestustest pidada: Artiklite kogumik. Tallinn: Eesti Raamat, cc. 91-130.

Jaaniste, Jaak \& Saar, Enn 1990. Täheatlas: Käsiraamat. [Атлас звезд.] Tallinn: Valgus.

Jakobson, Carl Robert 1868. Weikene Geograafia ehk Maadeteaduse käsiraamat 1-3. [Короткая география, или справочник для науки о земле.] Tartu: H. Laakmann.

Jakobson, Carl Robert 1868; 1913. Kooli lugemise raamat. [Школьная книга для чтения.] Tartu: H. Laakmann

Kampmann, Mihkel (= Kampmaa, Mihkel) 1913. Kooli Lugemisraamat 2. 3., täiend trükk. [Книга для школьного чтения.] Tallinn: G. Pihlakas.

Kaplinski, Jaan 1970. Mõned “Tähe mõrsjast” virgutatud mõtted. Keel ja Kirjandus 9, cc. 543-550.

Kasak, Enn 1996. Tähistaeval põhinevatest uskumustest. 1: Uskumuste liigitusest astronoomi pilguga. Mäetagused 1/2, cc. 24-29. 
Kasak, Enn 1999. Tähistaeval põhinevatest uskumustest 2: Astroloogiast Mesopotaamias. Mäetagused 10, cc. 38-54.

Kasak, Enn 2000. Beliefs based on the starry sky. Anu Nurk, Triinu Palo, Tõnu Seilenthal (ред.). Congressus Nonus Internationalis Fenno- Ugristarum: 7.-13.8.2000 Tartu 3: Summaria acroasium in sectionibus et symposiis factarum: Folkloristica \& Ethnologia; Litteratura; Archaeologia \& Anthropologia \& Genetica. Tartu: Eesti Fennougristide Komitee, c. 41.

Kasak, Enn \& Veede, Raul 2000. Mesopotaamia planeedinimedest ehk kurva lõpuga lugu. Akadeemia 6, cc. 1223-1246.

Kreutzwald, Friedrich Reinhold 1848-1849. Ma-ilm ja mõnda, mis seal sees leida on: Tullosaks ja öppetlikuks aeawiteks Ma-rahwale I-V. [Мир и его составляющие.] Tartu: [s.n].

Kuperjanov, Andres 1998. Täheonu: Maailmaruumi tühjusest, külatähetornidest ja Hugo Raudsaarest eriti. Mäetagused 7, cc. 57-65.

Kuperjanov, Andres 2000a. Ernekahl ja Taivatahr. Vaatleja: Hüperajakiri 3. http://www.obs.ee/cgi-bin/w3-msql/vaatleja/artikkel.html?id=119.

Kuperjanov, Andres 2000b. Koodid - rehad. Vaatleja: Hüperajakiri 1. http:// www.obs.ee/cgi-bin/w3-msql/vaatleja/artikkel.html?id=29.

Kuperjanov, Andres 2000c. Loogatähed ja Vändatähed. Vaatleja: Hüperajakiri 2. http://www.obs.ee/cgi-bin/w3-msql/vaatleja/artikkel. html?id=61.

Kuperjanov, Andres 2000d. Taeva sõelad. Vaatleja: Hüperajakiri 6. http:// www.obs.ee/cgi-bin/w3-msql/vaatleja/artikkel.html?id=209.

Kuperjanov, Andres 2003. Eesti Taevas. Uskumusi ja Tõlgendusi. [Эстонское небо. Исследования и интерпретации.] Tartu: Eesti Folkloori Instituut.

Kõiva, Mare 1983. Paleoastronoomiliselt müütidest ja muististest [Konverents: 21.04.1983, Viljandi]. Looming 6, cc. 847-848.

Kõiva, Mare \& Pustõlnik, Isold \& Vesik, Liisa 2005. Cosmic Catastrophes. A Collection of Articles. Proceedings of the Society for Astronomy in Culture (SEAC). Tartu: Estonian Literary Museum \& Tartu Observatory.

Kõiva, Mare 2007. Komeedid Eesti rahvausundis. Sator 6. Tartu: Eesti Kirjandusmuuseumi teaduskirjastus. 
Kõiva, Mare \& Kuperjanov, Andres (составители) 2012. Uudistades Universumit. Paar Sammukest XXVI 2012. Eesti Kirjandusmuuseumi aastaraamat. Tartu: Eesti Kirjandusmuuseumi teaduskirjastus.

Lintrop, Aado 2000. Suur tamm ja õde-venda. Mäetagused 13, cc. 24-42 (http://haldjas.folklore.ee/tagused/nr13/).

Livländer, Robert Johannes 1923. Vanade saarlaste täheteadus praegusel ajal: Mõned märkused ja lisandused Dr. J. Hurti "Eesti astronoomiale". Loodus 8, cc. 484-494.

Loorits, Oskar 1939. Rahvapärimuste koguja kutsumusest. Rahvapärimuste Selgitaja 6. Tartu, cc. 177-183.

Loorits, Oskar 1949. Grundzüge des estnischen Volksglaubens 1. Skrifter Utgivna av Kungl. Gustav Adolfs Akademien för Folklivsforskning 18 (1). Lund: Carl Blom.

Loorits, Oskar 1957. Grundzüge des estnischen Volksglaubens 3. Skrifter Utgivna av Kungl. Gustav Adolfs Akademien för Folklivsforskning 18 (3). Lund: Carl Blom.

Marpurg, Georg Gottfried 1805. Weikenne oppetusse nink luggemisse Ramat Tarto ma-rahwa kooli laste tarbis. [Небольшой учебник и читатель; для сельских школ.] Tartu: Georg Gottfried Marpurg.

Masing, Uku 1995. Eesti usund. [Эстонское верование.] Tartu: Ilmamaa.

Paulson, Ivar 1966. Vana Eesti rahvausk: Usundiloolisi esseid. [Давняе эстонское народное верование. Религиоведческое эссе.] Stockholm: Vaba Eesti.

Poikalainen, Väino \& Ernits, Enn 1987. Äänisjärve kaljujoonised ja esivanemate loodusetunnetus 1-2. Eesti Loodus 3, cc. 175-183; 4 , cc. $253-258$.

Poikalainen, Väino \& Ernits, Enn 1998. Rock Carvings of Lake Onega: Vodla Region. Tartu: Estonian Society of Prehistoric Art.

Prüller, Paul-Egon 1968. Eesti rahvaastronoomia. Teaduse ajaloo lehekülgi Eestist: Kogumik. Tallinn: Valgus, cc. 9-70.

Roos, Eduard 1969. "Tähe mõrsja" Salme ja tema kosilased. Keel ja Kirjandus 11, cc. 658-670. 
Salve, Kristi 1983. Paleoastronoomia müütides ja muististes [Konverents: 21.04.1983, Viljandi]. Keel ja Kirjandus 8, cc. 459-460.

Stahl, Heinrich 1637. Anführung zu der Ehstnischen Sprach, auff Wolgemeinten Rath, und Bittliches Ersuchen. Reval: H. Stahl.

Tago, Erik 1997. Sabatähed, mis tegid ajalugu. Mäetagused 3, cc. 53-56. Tuvikene, Tõnu 1998. Marsi kanalite ajalugu. Mäetagused 6, cc. 49-55. Vestring, Salomo Heinrich. Lexicon Esthonico Germanicum (http:// haldjas.folklore.ee/ kriku/VESTRING/index.htm).

Viires, Ants 1991. Pseudomythology in Estonian publicity in the 19th and 20th century. Ethnologia Europea 21 (2), cc. 137-143.

Viluoja, Eha 1980. Paleoastronoomia ja -matemaatika konverents [Konverents: 14.10.1980, Tallinn]. Keel ja Kirjandus 2, cc. 126-127.

Wiedemann, Friedrich Johann 1869 (1893). Ehstnisch-Deutsches Wörterbuch. Sankt-Peterburg: Kaiserliche Akademie der Wissenschaften.

Wiedemann, Friedrich Johann 1876. Aus dem inneren und äusseren Leben der Ehsten: Der Akademie vorgelegt am 30. Sept. 1875. SanktPeterburg: Kaiserliche Akademie der Wissenschaften.

\section{Summary}

\section{On Astral Mythology and Its Studies}

\section{Andres Kuperjanov}

Keywords: archeoastronomy, ethnic astronomy, folk astronomy, folk belief, history of studies, paleoastronomy

Astral mythology has long been studied in Europe. The study is closely connected with the discovery and interpretation of antiquities. FinnoUgric (including Baltic Finnic) astral folklore and mythology have also been collected, published, and studied extensively. Therefore, we can make some generalizations based on the previous research and raise new tentative research questions.

In 1902 a prominent Estonian folklore collector Jakob Hurt published a book on Estonian astronomy. In 1968 an overview was published by a physicist Paul-Egon Prüller. Both publications are empirical systematizations, and focus primarily on the names of the stars, leaving myths 
and beliefs aside. Meanwhile, plenty of astral myths were included in the compulsory school literature list for more than a hundred years. Anders Kuperjanov's 2004 book "Eesti taevas. Uurimusi ja tõlgendusi" (Estonian Sky: Studies and Interpretations) uses all the data of the folklore archive and the Estonian language archive, and provides the first systematic overview of astral beliefs, their practical use (to find out time and direction), and astral myths, and includes an additional star names catalogue. The book also features a star sky map with Estonian folk star names. Some of the less wide-scale studies of Baltic Finnic traditions based on fieldwork and printed data were published on Votes' and Livonians' folklore.

All Baltic Finnic corpora indicate that the collection of folk astral knowledge started too late and a number of mistakes were made in collection planning. Nevertheless, Baltic Finnic beliefs have common features, myths have much in common with Slavic and German ones, but they also have some peculiarities and motifs that emerged in the 20th century. The key issue now is how and what aspect of astral mythology we should collect in order to expand the previous data and get new ones. 


\section{МИССИЯ ВЫПОЛНИМА Перспективы изучения фольклора}

http://www.folklore.ee/rl/pubte/ee/sator/sator19/

ISSN 1736-0323

ISBN 978-9949-586-60-8

DOI: $10.7592 /$ Sator.2018.19

Тарту 2018

Редакторы-составители выпуска:

Маре Кыйва \& Татьяна Володина

Редактор серии: Маре Кыйва

Фото: Яак Кикас, 2018 «Осень в Тарту»

Оформление обложки: Лииса Весик

Верстка \& HTML: Диана Кахре

Печатное издание: МИССИЯ ВЫПОЛНИМА:

Перспективы изучения фольклора. SATOR 19. Тарту 2018

Публикация книги осуществлена совместно Эстонским литературным музеем и Центром исследований белорусской культуры, языка и лит ерат уры Националь ной акад емии наук Б еларус и, п ри поддержке Министерства образования и науки Эстонии (IUT 22-5), Фонда регионального развития ЕС (ТK 145, Центр компетенции по Эстонским исследованиям); при поддержке проекта, финансируемого Министерством иностранных дел Эстонии из бюджета по сотрудничеству и развитию, Эстонской Академией Наук и Национальной академии наук Беларуси.

Оформление электронного издания осуществлено при поддержке проекта ЕККМ14-344 “Расширение областей применения и представление эстонского языка, культуры и фольклора в электронных информационных средствах".

() Эстонский литературный музей

(c) Авторы

(с) Яак Кикас 